\title{
A Strobilanthes (Acanthaceae) miscellany
}

\author{
John R. I. Wood ${ }^{1,2}$ (D) \& R. W. Scotland ${ }^{1}$
}

Summary. This paper presents miscellaneous, previously unpublished results arising from the authors' research into Strobilanthes. S. moylaniae J.R.I.Wood \& Scotland from New Guinea and S. dengii J.R.I.Wood \& Scotland from Sumatra are proposed as new species, while an unnamed species is described from Sumba Island in Indonesia in the hope that it might be rediscovered. A new subspecies, subsp. subovata J.R.I.Wood \& Scotland is described for S. timorensis Nees, while attention is drawn to its plietesial flowering pattern. The new combinations $S$. benculensis (Bremek.) J.R.I.Wood \& Scotland, S. wetarensis (Bremek.) J.R.I.Wood \& Scotland, S. javanica (Bremek.) J.R.I.Wood \& Scotland and S. serpens (Nees) J.R.I. Wood \& Scotland are made. Typification is clarified and where appropriate lectotypes are designated for Hemigraphis hispidula Craib, Lepidagathis setigera Blume, Ruellia crispa L., R. sabiniana Lindl., Strobilanthes duclouxii Benoist, S. erecta C.B.Clarke, S. flava Kurz, S. forrestii Diels, S. scabra Nees, S. secunda T.Anderson and S. thomsonii T.Anderson.

Key Words. Hemigraphis, Lepidagathis, new combinations, new species, plietesial flowering, Sericocalyx, typification.

\section{Introduction}

Strobilanthes Blume is the second largest genus of Acanthaceae with around 400 - 420 accepted species according to our estimate and if a broad concept of the genus is accepted. It is almost entirely Asian in its distribution, extending from Japan and Korea in the north, from Afghanistan and Pakistan in the west and just reaching northern Australia in the south. It is most diverse in the Indian subcontinent, south China and mainland South East Asia but many species also occur in island South East Asia. The genus is remarkable for the diversity of its pollen (Carine \& Scotland 1998; Wood et al. 2003; Wood \& Scotland 2009; Hu Chia-chi et al. 2011) and the plietesial flowering pattern of many species (Wood 1994b). Although several species are widely distributed (Bennett et al. 2008), most are rare and localised in their distribution (Wood \& Scotland 2009). Most grow in hill forest in areas with a seasonally dry monsoon climate and the genus is noticeably less diverse in tropical rain forest. A few species reach altitudes above $3000 \mathrm{~m}$ in the Himalayas and SW China (Hu Chia-chi et al. 2011) but most are found at lower altitudes. Several species are cultivated both in temperate and tropical regions and are occasionally reported as naturalised outside their native range (Wood 2014).

Over the last 25 years, the authors and various colleagues have published a series of papers on the distribution, characteristics, systematics and taxonomy of Strobilanthes but there remain a number of matters that await publication. This paper aims to tidy up miscellaneous issues left over from these studies or which have arisen from the study of specimens received on loan. In particular, two descriptions resulting from Elizabeth Moylan's work on Hemigraphis Nees (Moylan et al. 2002, 2004) are still pending. A number of generic transfers are needed and the opportunity is taken to lectotypify several species whose typification is ambiguous.

We accept a broad concept of Strobilanthes following Terao (1983) based on our own morphological (Wood 1994b; Carine \& Scotland 2002; Wood \& Scotland 2009) and molecular studies (Moylan et al. 2004). These results have been confirmed by other studies (Tripp et al. 2013) and are now generally accepted (Hu et al. 2011; Augustine 2018; Deng 2019). Essentially, this means that all genera placed in the Strobilanthinae sensu Bremekamp (1944) belong to the genus Strobilanthes, including species placed both in Hemigraphis and Sericocalyx Bremek.

\section{Materials and Methods}

This paper is based on the study of herbarium specimens, principally those received on loan from $\mathrm{BM}, \mathrm{K}$ and L. Extensive use has been made of on-line resources, particularly the literature available through the Biodiversity Heritage library and the specimen images on Jstor. Images available on the websites of individual herbaria, especially those of Kew (K), Edinburgh Botanic Garden (E), Naturalis in the Netherlands (L, U) and The Natural History Museum,

Accepted for publication 17 April 2021. Published online 7 December 2021

1 Department of Plant Sciences, University of Oxford, Oxford, OX1 3RB, UK. e-mail: jriwood@hotmail.com

2 Royal Botanic Gardens, Kew, Richmond, Surrey, TW9 3AB, UK. 
Paris (P) have also proved very useful. All cited specimens have been seen unless indicated to the contrary. The original work of Elizabeth Moylan as part of her DPhil studies of species placed originally in Hemigraphis has also provided valuable insights although she is not responsible for decisions we have made in this paper.

\section{New taxa}

Strobilanthes moylaniae J.R.I.Wood E S Sotland, sp. nov. Type: Papua New Guinea, Tovobada Hills, Waigani village, 10 May 1967, R. Pullen 6946 (holotype CANB171572, isotypes $\mathrm{K}, \mathrm{L}-2824954$, also said to be at A, LAE).

http:/ /www.ipni.org/urn:lsid:ipni.org:names:77220443-1

Prostrate herb, rooting at the nodes, stems eventually ascending, terete, pubescent. Leaves petiolate, $1.8-4 \times$ $1-2.2 \mathrm{~cm}$, ovate-elliptic to oblong-elliptic, tapering at the base into the petiole, apex obtuse, margin crenate, both surfaces adpressed pilose and somewhat asperous, abaxially paler; petioles $5-13 \mathrm{~mm}$, pubescent. Inflorescences terminal and pedunculate from the uppermost leaf axils, dense, subcapitate, pubescent with prominent white, glandular hairs; peduncles $0.2-$ $1.5 \mathrm{~cm}$; bracts subtending a single flower, $10-13 \times 3-$ $4 \mathrm{~mm}$, oblong-elliptic to subrhomboid, obtuse to subacute, crenate, pubescent with white, gland-tipped hairs; bracteoles absent; calyx subequally 5-lobed, the lobes linear, $8 \times 0.5 \mathrm{~mm}$, shortly glandular-pilose; corolla lilac, funnel-shaped above a cylindrical basal tube, c. $15 \mathrm{~mm}$ long, 5-lobed, the lobes oblong, rounded, c. $2 \times 1 \mathrm{~mm}$; long filaments c. $4 \mathrm{~mm}$ long, pubescent in lower half, held at corolla mouth, short filaments c. $1 \mathrm{~mm}$ long, glabrous; anthers $1 \mathrm{~mm}$ long; pollen c. $30 \times 20 \mu \mathrm{m}$, ellipsoid, bireticulate, c. $20-$ ribbed; ovary oblong-ovoid, glandular; style c. $12 \mathrm{~mm}$ long, glandular below. Capsule linear-oblong in outline, $6 \times 1 \mathrm{~mm}$, 8-seeded, retinacula short, stubby; seeds lenticular, c. $1.25 \mathrm{~mm}$ diam., shortly pubescent. Fig. 1.

RECOGNITION. Strobilanthes moylaniae is superficially similar to S. reptans (G.Forst.) Y.F.Deng \& J.R.I.Wood in its habit and the absence of bracteoles. However, the new species is easily distinguished from S. reptans by the glandular (not multicellular) hairs on the bracts, calyx and ovary, flowers with stamens held at the corolla mouth (not included) and longer filaments that are pubescent (not glabrous) in the lower half.

Distribution \& hABITAT. Papua New Guinea. Light scrubby woodland at c. $90 \mathrm{~m}$.

CONSERVATION STATUS. This species is only known from the type collection made over 50 years ago. This may reflect genuine rarity but equally it could have been overlooked because of its strong superficial similarity to Strobilanthes reptans. Any attempt to categorise this species within IUCN (2012) categories would be premature so it must be treated as Data Deficient (DD) until careful search for it is made near the type locality in Papua New Guinea.

ETYMOLOGY. This species is named after Elizabeth Moylan who made a major study of species treated as Hemigraphis (Moylan et al. 2002, 2004). She separated out this specimen as a putative new species but never described it.

NOTE. The pollen of this species (Fig. 2) is clearly ellipsoid and similar in shape and ornamentation to that of Strobilanthes tomentosa (Nees) J.R.I.Wood illustrated by Wood \& Scotland 2009: 8 and Hu Chia-chi et al. 2011: 382. The ellipsoid shape is different from the spheroidal pollen of $S$. reptans (Nurulaini et al. 2017) but it is highly likely that the pollen of S. reptans is more variable than implied by this illustration.

Strobilanthes dengii J.R.I.Wood E Scotland, sp. nov. Type: Indonesia, Sumatra, Tipanuli Residency, Lae Pondon, E of Sidikalang, 29 March 1954, A. H. G. Alston 14958 (holotype BM, isotype U, ?BOGOR).

http:/ /www.ipni.org/urn:lsid:ipni.org:names:77220444-1

Subshrub c. $3 \mathrm{~m}$ in height; stems stout, woody, much branched, obscurely winged, somewhat pustulate, bifariously scurfy-pubescent, glabrescent when old. Leaves shortly petiolate, $1-3.5 \times 0.5-1.8 \mathrm{~cm}$, ovate, acuminate, base attenuate and decurrent onto the petiole, margin serrate, both surfaces glabrous except a few appressed hairs on midrib near base, abaxially paler; petioles $1-5 \mathrm{~mm}$. Inflorescence of numerous, axillary, bracteate cymes mostly with $3-5$ flowers; bracts resembling small leaves, mostly $5-10 \times 3-5$ $\mathrm{mm}$; calyx subequally 5-lobed to the base, glabrous, lobes linear, obtuse, at anthesis c. $7 \times 0.5 \mathrm{~mm}$ but strongly accrescent to $15 \times 1 \mathrm{~mm}$; corolla "mauvewhite", glabrous, \pm funnel-shaped, the short basal cylindrical tube $2-3 \times 1.5 \mathrm{~mm}$, then bent slightly and gradually widened for c. $18 \mathrm{~mm}$ to $10 \mathrm{~mm}$ at the mouth, the limb 5-lobed with rounded ovate lobes c. 2 $-3 \times 2-3 \mathrm{~mm}$; stamens didynamous, longer filaments pilose, c. $7 \mathrm{~mm}$ long, shorter filaments glabrous, c. $2 \mathrm{~mm}$ long; anthers $2 \times 0.5 \mathrm{~mm}$, included; style glabrous, $12 \mathrm{~mm}$ long. Capsule oblong, $12-15 \times 3$ $\mathrm{mm}$, glabrous, 4-seeded; seeds lenticular, pubescent. Fig. 3.

RECOGNITION. Resembling Strobilanthes atropurpurea Nees in the leaf shape, subequally lobed calyx with linear, obtuse lobes and the glabrous corolla, ovary and capsule but readily distinguished by the very robust, shrubby habit, axillary cymose inflorescences 


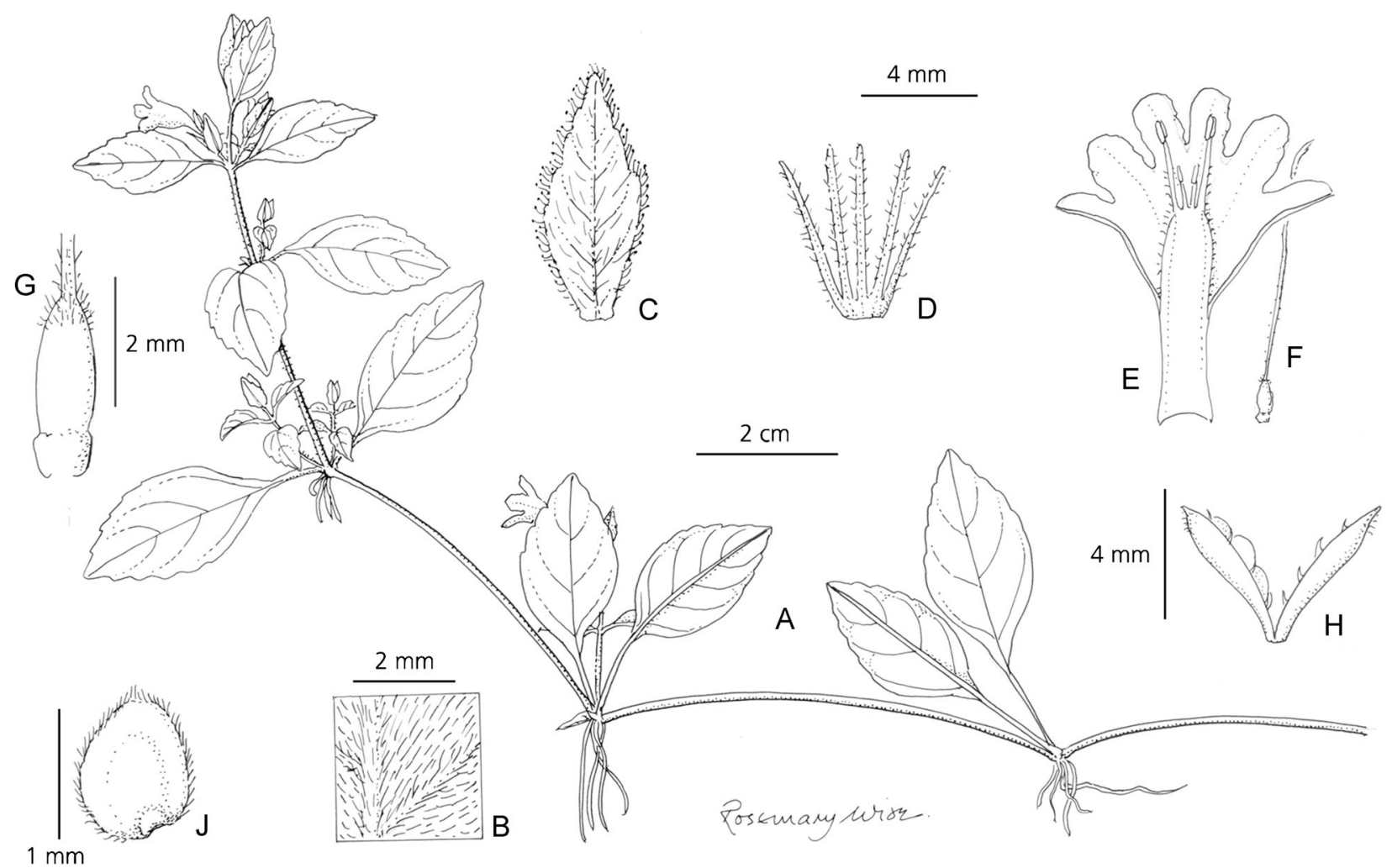

Fig. 1. Strobilanthes moylaniae. A habit; B abaxial leaf surface; C bract; D calyx; E corolla opened out showing stamens; $\mathrm{F}$ ovary and style; G apex of ovary and base of style; H capsule; J seed. From Pullen 6946.

(not flowers in 1-sided racemes, often reduced to solitary axillary flowers) and in the smaller, narrowly funnel-shaped corolla less than $10 \mathrm{~mm}$ wide (not strongly ventricose, up to $20 \mathrm{~mm}$ wide).

DISTRIBUTION \& HABITAT. Not known, presumably forest.

CONSERVATION STATUS. This species is only known from the type collection made over 65 years ago. This may reflect genuine rarity or the destruction of the

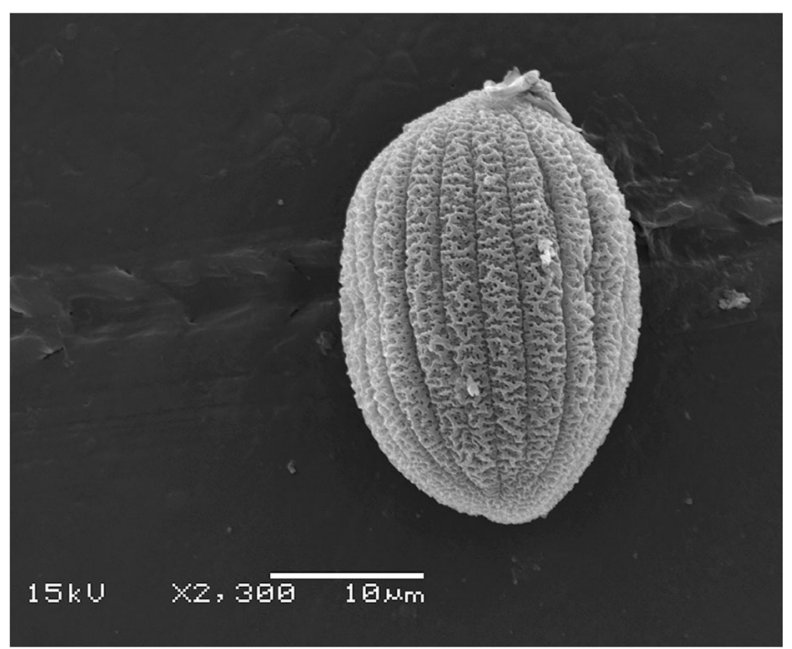

Fig. 2. Strobilanthes moylaniae. SEM photograph of pollen of Pullen 6946. original habitat, but equally may reflect the lack of recent collecting in the area. There are reports of coffee plantations in the region but whether these affect the type locality is unknown. It must be classified as Data Deficient within IUCN (2012) guidelines until further information becomes available.

ETYMOLOGY. This species is named after our colleague Deng Yunfei, who has published extensively on the Acanthaceae and other aspects of the Chinese flora. $\mathrm{He}$ has collaborated with the authors on various papers on Strobilanthes and drew our attention to the distinctiveness of this species.

NOTE. This species was separated out as a novelty by Hiroshi Terao but was never published. We were inclined to think of it as a form of the variable Strobilanthes atropurpurea until Deng Yunfei drew our attention to its distinct characteristics. Not only is it far more robust but the inflorescence is not composed of one-sided racemes, nor reduced to single axillary flowers. Most distinct of all is the smaller infundibuliform corolla which lacks the distinct ventricose bulge of $S$. atropurpurea. It is possible that two other collections from North Sumatra, Bartlett 8494 (US) from Deleng Baroes, Karo and Van Steenis 9349 (L) from Gadjah-Blang Kedjeren in Gajolanden, belong to this species but they differ somewhat from Alston 14958 and a final decision must await further collections, which may help show the range of 

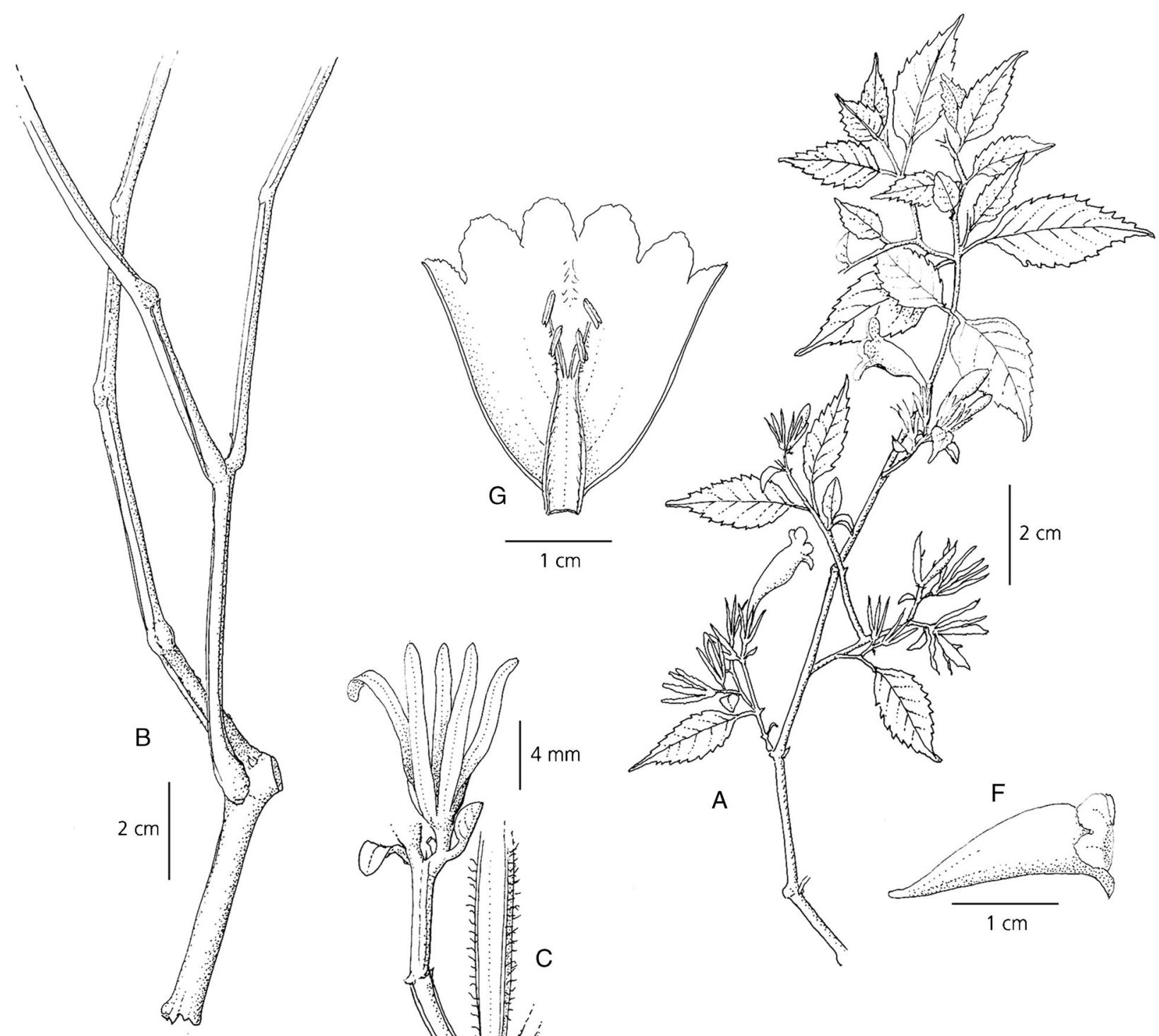

$\mathrm{D}$

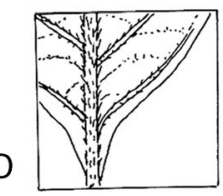

$4 \mathrm{~mm}$

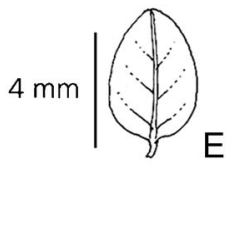

$$
\text { Rosematy wisz. }
$$

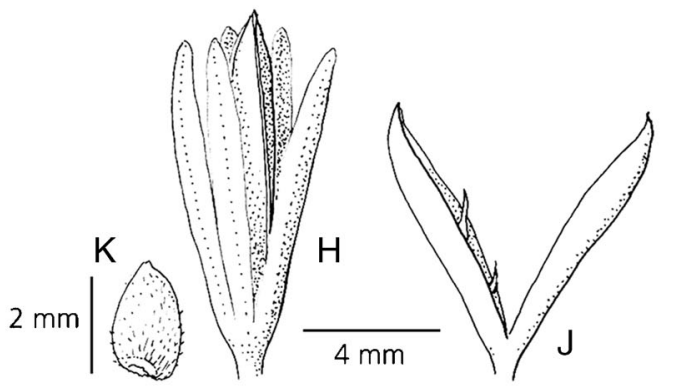

Fig. 3. Strobilanthes dengii. A habit with flowers; B mature leafless stem; C detail of stem with base of inflorescence; D leaf base; $E$ bract; F corolla, side view; G corolla opened out to show stamens; H capsule within calyx; J capsule opened out to show retinacula; K seed. From Alston 14958. DRAWN BY ROSEMARY WISE.

variation in Strobilanthes dengii.

\section{Strobilanthes sp.}

Erect isophyllous shrub; stem glabrous. Leaves petiolate; petioles $0.5-0.7 \mathrm{~cm}$, lamina $6-13 \times 3-4.6 \mathrm{~cm}$, lanceolate to ovate, tapering to an acuminate apex and narrowly cuneate base, margin entire to obscurely undulate, both surfaces glabrous, adaxially with prominent cystoliths, abaxially paler. Inflorescence terminal, consisting of $1-3$ condensed thyrses, glandular-pilose with stipitate glands, c. $2.5-3 \mathrm{~cm}$ long (immature), 
the conspicuously glandular hairs present on bracts, calyx and corolla; peduncles c. $7 \mathrm{~mm}$ long; bracts oblong-elliptic, 8 - $9 \mathrm{~mm}$ long, each subtending two flower buds; bracteoles absent; calyx subequally 5lobed to base, lobes linear, acute, $7 \mathrm{~mm}$ long, $0.25 \mathrm{~mm}$ wide, glandular-pilose; corolla c. $10 \mathrm{~mm}$ long, glandular hairy, colour unknown, longer and shorter filaments glabrous; pollen ellipsoid, $60 \times 40 \mathrm{um}$; ovary comose with 8 ovules, style pubescent. Capsule not seen. Fig. 4.

RECOGNITION. This undescribed species resembles Strobilanthes linearifolia (Bremek.) Y.F.Deng (=Hemigraphis ciliata S.Moore) in the leaf shape, small, terminal inflorescence and absence of bracteoles but is a subshrub, the calyx is larger ( $7 \mathrm{~mm}$ long, not < $5.8 \mathrm{~mm}$ long) and all filaments are glabrous.

DISTRIBUTION. Indonesia.

SPECIMEN EXAMINED. INDONESIA. Soemba (Sumba): Kadoemba; [10 - 11 Sept. 1873, fide Flora Malesiana ser. 1, 1: Cyclopaedia of collectors (Steenis 1950)], J. E. Teysmann 1910 (Distribution No. 8878) (K, L-2824911, SING).

NOTE. This species collected almost 150 years ago was separated out by Elizabeth Moylan and appears to be distinct. Although we have not formally described it as new, a full description is provided in the hopes that someone may be motivated to explore the island of Sumba and rediscover it. All the available information is provided above and in the accompanying Fig. 4. Some details are based on C. B. Clarke's sketch which is clearly visible in Fig. 4.

Strobilanthes timorensis Nees (1847: 178). Type: Timor, sine data et col. (holotype GZU-000268994).

Sericocalyx timorensis (Nees) Bremek. (Bremekamp 1944: 161).

Sericocalyx timorensis var. quadriovulatus Bremek. (Bremekamp 1944: 162). nom. superfl., autonymic variety.

Perennial herb, stems hispid, becoming woody and erect, reaching at least $2 \mathrm{~m}$ (fide Schmutz 6165). Leaves $3-12 \times 0.5-5 \mathrm{~cm}$, oblong-lanceolate, acuminate, narrowed at base into a slightly winged petiole 1 $2 \mathrm{~cm}$ long, margin repand, lateral veins c. 7 pairs, both surfaces scabrid, adaxially shiny. Inflorescence terminal and axillary, often forming a loose, leafless branched thyrse, the branches up to $10 \mathrm{~cm}$ long, the flowers arranged in short bracteate spikes at the branch tips; spikes $1.5-4 \mathrm{~cm}$ long; bracts $7-12 \times 2-5 \mathrm{~mm}$, oblong-lanceolate to ovate, acuminate, obtuse, asperous-pilose, the whitish hairs sometimes glandular apically; bracteoles c. $5 \times 0.75 \mathrm{~mm}$, linear; calyx c. $8 \mathrm{~mm}$ long, slightly unequally lobed to just above the base, lobes linear, $1 \mathrm{~mm}$ wide, longest lobe c. $8 \mathrm{~mm}$, shorter lobes $6 \mathrm{~mm}$, pilose with gland-tipped hairs; corolla c. $13 \mathrm{~mm}$ long, pubescent, yellow, the lobes c. $3.5 \mathrm{~mm}$ long; longer filaments $3.5 \mathrm{~mm}$, shorter filaments $2 \mathrm{~mm}$; anthers included. Capsule oblong in outline, $8.5-10 \times 2 \mathrm{~mm}$, shortly comose with glandtipped hairs, 4 - 6-seeded; seeds c. $2 \times 1.5 \mathrm{~mm}$, lenticular, pubescent.

Bremekamp (1944) treated this species as belonging to Sericocalyx (as S. timorensis (Nees) Bremek.) and divided it into two varieties, var. quadriovulatus Bremek., a superfluous name for the type variety and var. sexovulatus Bremek., the varieties distinguished by the number of ovules, four in the first case but six in the second. As the number of ovules and seeds is quite variable in several species referred previously to Aechmanthera (Wood \& Scotland 2009: 16), Hemigraphis (Moylan et al. 2002: 785, 790, 794, 812 etc.) or Sericocalyx (Kurz 1871: 74 in discussion of Strobilanthes flava), this character is of little value, particularly as it shows no correlation with other characters or any geographical or ecological patterning. However, examination of around 25 specimens of Strobilamthes timorensis indicates that this species can be divided into two geographically distinct subspecies based on the shape of the bracts, lanceolate to oblong in the type subspecies but ovate to elliptic in the subspecies ovata described below. Subsp. timorensis is more eastern in its distribution than subsp. ovata.

subsp. timorensis

RECOGNITION. Bracts lanceolate to oblong-lanceolate, narrowed to an acute apex. Capsule 4-seeded (where known).

Distribution \& HABITAT. Timor and the neighbouring islands of Alor, Flores and Moa between 250 and $1000 \mathrm{~m}$ (Map 1). It is not recorded who made the type collection or whether it was found in East or West Timor, but the two collections cited below are from West Timor Zippelius is known to have been based in Kupang in Indonesian (West) Timor.

SPECIMENS EXAMINED. INDONESIA. West Timor: Without data, Zippelius s.n. (L-2834256, L-2834261), ex Herb Paris (L-2834259); Niki Niki, 750 m, 27 June 1964, C. Kooy 106A (L2834264). Flores: Near Ruteng West Flores, 1200 m, 22 April 1965, Kostermans E Wirawan 454 (L-2834258). Soenda Eil, West Flores 600 - 1000 m, 11 April 1967, E. Schmutz 1443 (L-2834265). Manggarai, Rangga, West Flores, 250 m, 9 July 1987, E. Schmutz 6165 (L-2842393/L-2834257). Alor: Lantoka-Mumang, Central highlands, 750 m, 17 May 1938, O. Jaag 1234 (BM, L-2834262). LantokaPido, Central highlands, 800 m, 18 May 1938, O. Jaag 1262 (L-2834263). Moa: 1883, Riedel s.n. (K). 


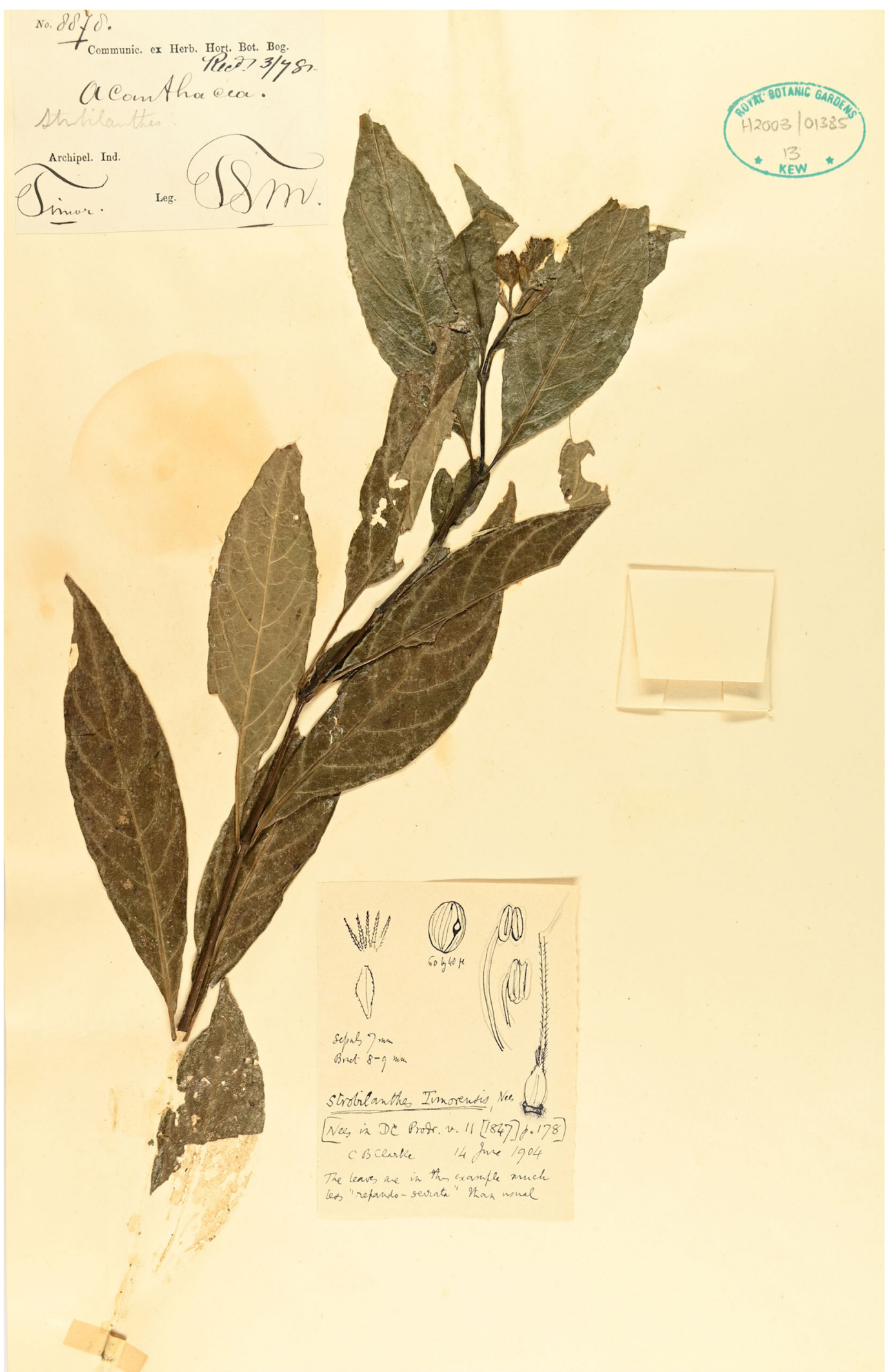

Fig. 4. Strobilanthes sp., Teysmann 1910 (K). 


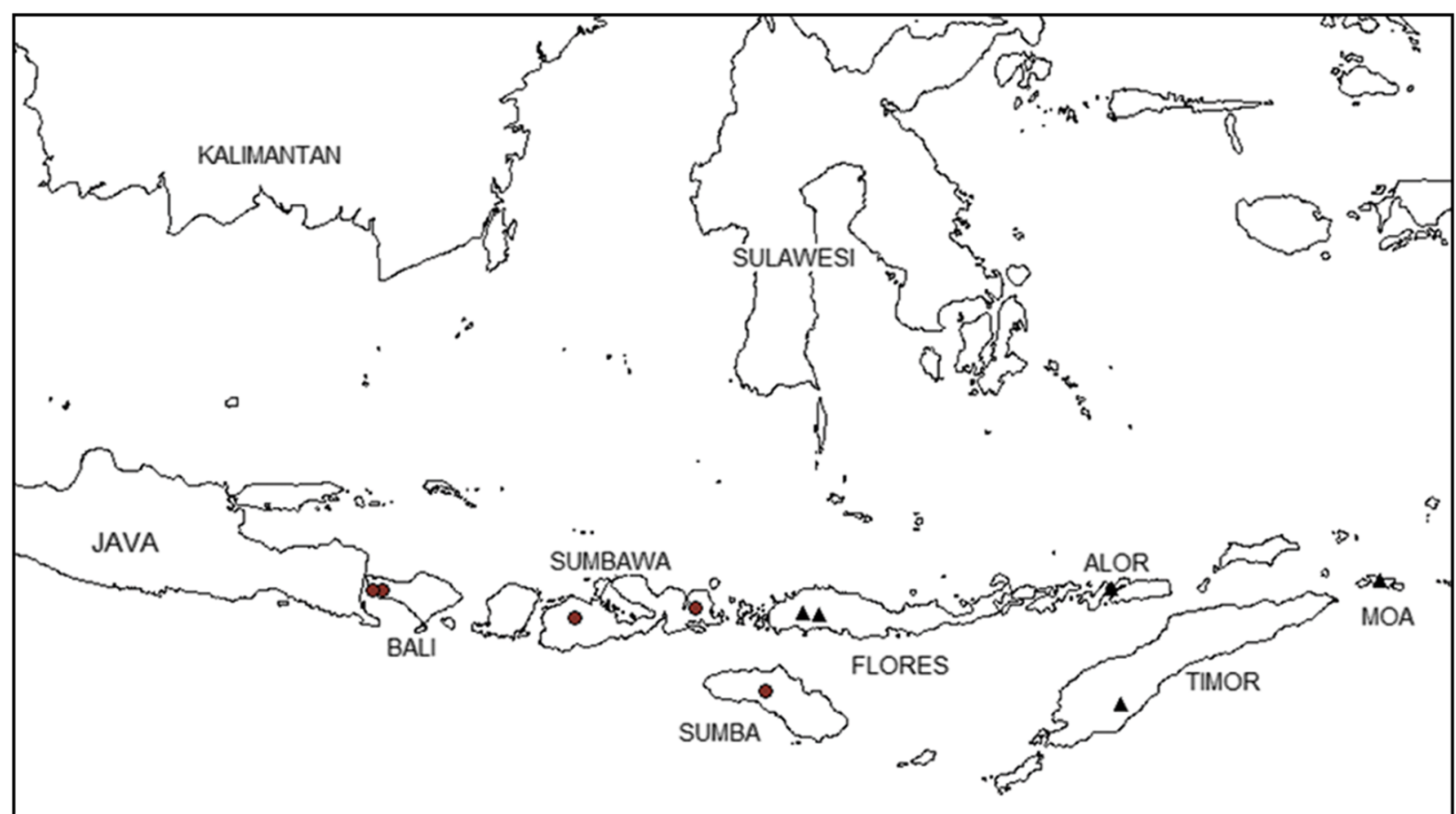

Map 1. Lesser Sunda Islands of Indonesia showing native distribution of Strobilanthes timorensis subsp. timorensis ( $\mathbf{\Delta})$ and subsp. subovata $(\bullet)$.

PHENOLOGY. Subspecies timorensis apparently flowers in the May to July period.

NOTES. The field notes accompanying Schmutz 6165 comment: "On July 91987 there were thickets of this plant in flower. If not distressed by Eupatorium odoratum, (they) will grow up to as tall as a man and more, and as thick as a walking stick, suitable for firewood ...... One year later, there are big masses of seedlings, sized between 5 and $22 \mathrm{~cm}$.....(on) August 271988 in Pouggeok/Ulung at $700 \mathrm{~m}$.... I met a few flowering specimens. They always reveal as being side shoots from early (before simultaneous flowering) cut main stems. Such often happens close to the road when people are cleaning up the road by cutting away all the weeds." He also noted seven-year flowering cycles and an unfounded folk legend that flowering announces a prolonged dry season (Schmutz 1988: 19). These field notes indicate quite clearly that this is a plietesial species, flowering gregariously in an approximately seven-year cycle. Although plietesial flowering has been known in Strobilanthes for two centuries (Bremekamp 1944; Wood 1994b), Schmutz' brief paper is only the second note of the phenomenon in the Malesian region after Van Steenis (1942).

Strobilanthes timorensis subsp. subovata J.R.I.Wood $\mathcal{E}^{2}$ Scotland, subsp. nov. Type: Indonesia, Bali, Zollinger 3801 (holotype W-1889-0169698, sheet at W with original label "3801 Strobilanthes ? Cor. lutea. In fruticetis et sylvis pr. Djembrana, Ins. Bali, 12 X 46 Zollinger", isotypes BM-001190988, K-0010968301, W-1889-0169699).

http:/ /www.ipni.org/urn:lsid:ipni.org:names:77220445-1

Sericocalyx timorensis var. sexovulatus Bremek. (Bremekamp 1944: 162). Type: Indonesia, Sumbawa, O. Warburg 17113 (holotype B-10-1184356).

RECOGNITION. Bracts ovate to ovate-elliptic $3-5 \mathrm{~mm}$ (not $<2 \mathrm{~mm}$ ) broad, acuminate. Capsule 6-seeded where known.

DISTRIBUTION \& HABITAT. Bali, Sumbawa, Sumba (Map 1). Records from Java are of cultivated plants. Scrub, mostly at lower altitudes than subsp. timorensis.

SPECIMENS EXAMINED. INDONESIA. Java: Bogor, probably all cultivated, without data, Nov. 1902, sine col. (NY); ibid., 22 Sept. 1954, Alston 17127 (BM013861726); ibid., 5 Feb. 1951, Nedi E Idjan 173 (L2834255); Graaf von Limburg Road, Buitenzorg, 250 m, 5 Nov. 1925, Danser 5594 (L-2834254). Bali: Djandikesoma (Candikesuma), 20 m, 13 Aug. 1910, Sarip 183 (L-2834249); Djembrana (Jembrana), the type. Sumba: 2 Dec. 1934, De Voogd 1862 (L-2834250). Sumbawa: Sambon, $3000 \mathrm{ft}$, [c. $900 \mathrm{~m}, 1880 \mathrm{~s}$, O. Warburg 17113 (B-10-1184356); Bima, Donggo, 250 - 500 m, 3 Dec. 1909, Elbert 3504 (L, K-00939205); Bima, Timtu, 75 - 250 m, 3 Dec. 1909, Elbert 3554 (L-28342452); Bima, Donggo, 100 - 300 m, 3 
Dec. 1909, Elbert 3596 (L-2834256, K-00939206); Bima, Doro-Kechi, Biusa, 10 - 150 m, 16 Dec. 1909, Elbert 3884 (L-2834246); Bima, Kologebirge (west side), 200 - 375 m, 9 Dec. 1909, Elbert 3693 (L-2834253); Mt Batalante, Semongkat, 300 m, 19 Oct. 61, Kostermans 19042 (C, K, L-2834248). Uncertain location, possibly Sumbawa: Riedel s.n. (K).

PHENOLOGY. Flowers August to February.

\section{New combinations}

As noted in the introductory section a broad concept of Strobilanthes is generally accepted today. The following species belonging to the Strobilanthinae sensu Bremekamp (1944) have never been transferred to Strobilanthes and the necessary combinations are made below. It is hoped that all recognised species of the Strobilanthinae now have a valid name within Strobilanthes.

Strobilanthes benculensis (Bremek.) J.R.I.Wood E Scotland, comb. nov.

http:/ /www.ipni.org/urn:lsid:ipni.org:names:77220446-1

Semnostachya benculensis Bremek., Verh. Kon. Ned. Akad. Wetensch. Afd. Nat., Sect. 2, 41 (1): 204 (Bremekamp 1944: 204). Type: Indonesia, Sumatra, Ajoeb (Exped. Jacobsen) 349 (holotype L-0002947).

DISTRIBUTION. Endemic to the Bengkulu area of western Sumatra.

SPECIMENS EXAMINED. INDONESIA. Sumatra: Bengkulu, Soobah Ajam, 1200 m, 12 July 1916, Ajoeb (Exped Jacobsen) 349 (L); Gunong Seminoong base, south of Lake Ranau, 650 m, 12 Nov. 1929, Van Steenis 3952 (L); Kaba, 1000 m, 18 March 1932, de Voogd 1329 (L); sin data, Forbes s.n. (BM). Padang, Barisan Range, near Air Sirah, $0^{\circ} 57^{\prime} \mathrm{S} 100^{\circ} 32^{\prime} \mathrm{E}, 5$ May 1996, de Vogel $\mathcal{E}^{\circ}$ Vermeulen 7437 (C, L). Aceh, Takigeon (Takengon), 1097 m, 7 Jan. 1932, W. E C. Bingham 731 (A, NY); Ketembe valley of Lau Alas, 200 - 400 m, 17 May 1972, de Wilde $\mathcal{E}^{\circ}$ de Wilde 12039 (L).

Strobilanthes wetarensis (Bremek.) J.R.I.Wood E Scotland, comb. nov.

http:/ /www.ipni.org/urn:lsid:ipni.org:names:77220447-1

Hemigraphis wetarensis Bremek., Verh. Kon. Ned. Akad. Wetensch. Afd. Nat., Sect. 2, 41 (1): 89 (Bremekamp 1944). Type: Indonesia, Lesser Sunda Islands, Wetar, Ilwaki, in Eucalyptus scrub, 150 - 550 m, Elbert 4427 (holotype L-0003024).
DISTRIBUTION. Endemic to Wetar in the Lesser Sunda Islands.

SPECIMENS EXAMINED. INDONESIA. Wetar: Tihusces, 485 - 500 m, Elbert 4548 (L). East Timor, c. 730 m, 3 July 1929, M. E. Walsh 479 (BM).

Strobilanthes javanica (Bremek.) J.R.I.Wood E Scotland, comb. nov.

http://www.ipni.org/urn:lsid:ipni.org:names:77220448-1

Hemigraphis javanica Bremek., Verh. Kon. Ned. Akad. Wetensch. Afd. Nat., Sect. 2, 41 (1): 89 (Bremekamp 1944). Type: Indonesia, Central Java P[B]rambanan, Junghuhn s.n. (L-2831943).

DISTRIBUTION. Endemic to Java and neighbouring islands. It is found mostly in East Java extending west to Prambanan in central Java and east to the island of Bali. SPECIMENS EXAMINED. INDONESIA. East Java: Between Tjerme and Krian, Dorgelo 1977 (L); Prov. Malang, Pasuruan, Backer 36991 (L-2831813); below Nongko Djadjar, Backer 37254 (L-2831809); Tengger Mts, Mousset 862 (L-2831819); Besuki Distr., Sumber Waru, Koorders 43876 (L-2831818), 47977 (L-2831821); sin. loc. De Vriese s.n. (L-2831816), Horsfield s.n. (K). Bawean Island, Gunung Besar (?Tinggi), Dorgelo 133 (L-2831812). Bali: Buleleng [Bulelang], A. H. G. Alston 17060 (BM).

NOTES. Bremekamp (1944: 89) equated all specimens from Java identified as Strobilanthes hirsuta Decne. (as Hemigraphis decaisneana Nees) with S. javanica, which is endemic to Java whereas $S$. hirsuta is endemic to Timor. S. javanica resembles $S$. hirsuta but can be distinguished from it (and also $S$. wetarensis) by the presence of bracteoles. It is also similar to S. brunelloides (Lam.) J.R.I.Wood but is distinguished by the subequally 5-lobed calyx (Fig. 5E), whereas $S$. brunelloides has 2-lipped calyx with upper lobes partially fused (Fig. 6F). The above specimens all seem to belong to $S$. javanica (Fig. 5).

Strobilanthes javanica has a strong superficial resemblance to $S$. pavala (Roxb.) J.R.I.Wood from India but differs in the presence of bracteoles and the glabrous filaments.

Strobilanthes serpens (Nees) J.R.I.Wood E Scotland, comb. nov.

http://www.ipni.org/urn:lsid:ipni.org:names:77220449-1

Ruellia serpens Nees, Prodr. [A. P. de Candolle] 11: 145 (1847). Type: Indonesia, Tjiserae, Java, Blume 1228 p.p. (holotype GZU-000250312, isotype L-0065807, 


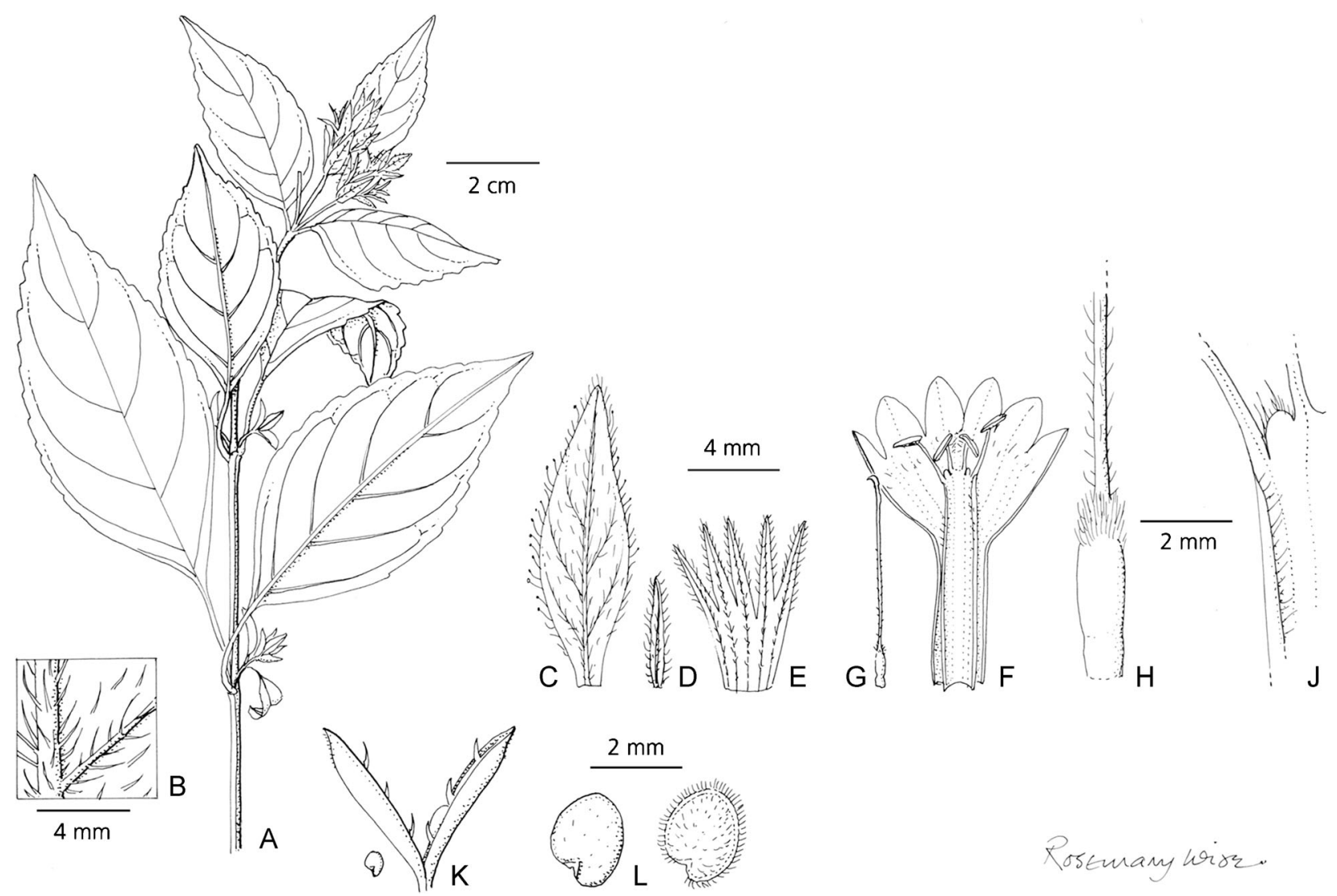

Fig. 5. Strobilanthes javanica. A habit; B abaxial leaf surface; C bract; D bracteole; E calyx; F corolla opened out showing stamens; $\mathrm{G}$ ovary and style; $\mathrm{H}$ apex of ovary and base of style; J gap between base of filaments; $\mathrm{K}$ capsule with seed to scale; $\mathrm{L}$ seeds, when dry (left), when wetted (right). From Alston 17060. DRAWN BY ROSEMARY WISE.

excluding portion on right labelled Lepidagathis setifera and bearing Bremekamp's annotation 'Lepidagathis sp. aff. javanica Bl.).

Hemigraphis serpens (Nees) Boerl. (Boerlage 1899: 658). Ruellia nemorosa Zoll. \& Moritzi (Zollinger \& Moritzi 1845: 574). Type: Indonesia, Java, 'in sylvis umbrosis regionis calcareae', 'ad rivulam Bantur, Prov. Malang', Zollinger 2374 (isotype P-00719213).

Hemigraphis nemorosa (Zoll. \& Moritzi) Bremek. (Bremekamp 1944: 95).

Hemigraphis ridleyi C.B.Clarke (1908: 652). Type: Malaysia, Pahang, Ridley 2180 (isotype SING-0027181).

Hemigraphis hispidula Craib (1913: 203). Type: Thailand, Hui Me Sakawn, between Pre and Nan, Kerr 2383 (lectotype K-000882584, designated here, isolectotype E-00273430).

Sericocalyx hispidula (Craib) Bremek. (Bremekamp 1944: 163).

DISTRIBUtION. Thailand, Peninsular Malaysia, Indonesia (Java).

NOTES. Hemigraphis nemorosa was distinguished from Strobilanthes serpens by having six, not four ovules but, as noted under $S$. timorensis, the number of ovules is variable within many species formerly placed in
Hemigraphis and Sericocalyx and is of little taxonomic significance. The only other differences adduced by Bremekamp relate to minor variations in indumentum. Consequently, Hemigraphis nemorosa is not recognised here as a separate species.

Blume 1228 is a mixed collection. Part of the collection represents Strobilanthes serpens (above) but the other part represents the following species of Lepidagathis:

Lepidagathis setigera Blume (1826: 802). Type: Indonesia, Java, Tjikao, Blume 1228 p. p. (lectotype L-0065807, small portion on right of sheet labelled Lepidagathis setigera and bearing Bremekamp's annotation 'Lepidagathis sp. aff. javanica Bl.', designated here).

The protologue as well as the collection represents a mixed gathering. The description of the stem and leaves refers to Strobilanthes serpens whereas the description of the inflorescence refers to Lepidagathis setigera, which is probably conspecific with Lepidagathis incurva Buch.-Ham. ex D.Don. It is lectotypified above to avoid any possible lectotypification of the name within Strobilanthes. 


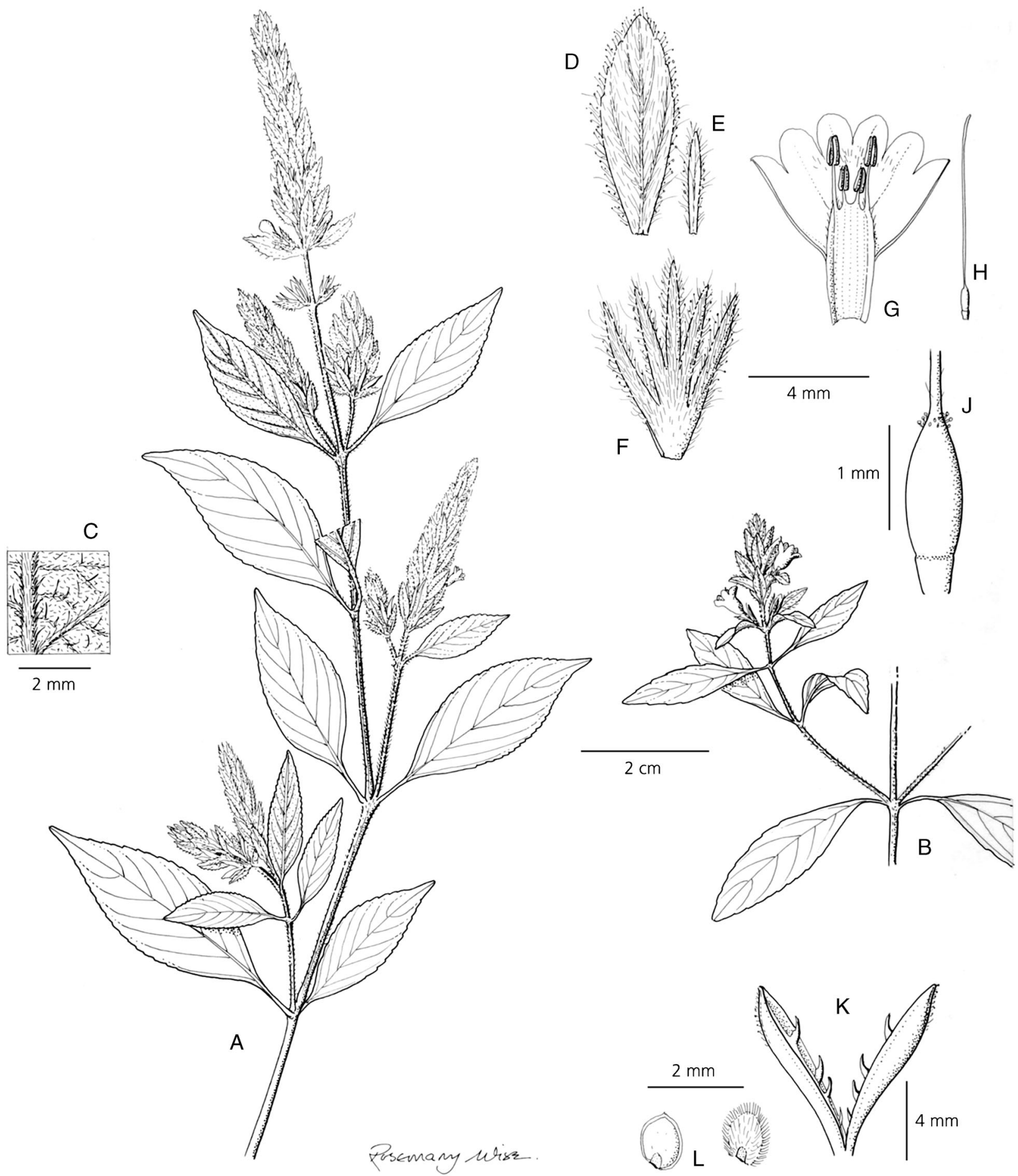

Fig. 6. Strobilanthes brunelloides. A habit; B flowering branch; C abaxial leaf surface; D bract; E bracteole; F calyx; G corolla opened out showing stamens; $\mathrm{H}$ ovary and style; J apex of ovary with glands and base of style; K capsule; $\mathrm{L}$ seeds when dry (left), when wetted (right). A, C - L from T. Horsfield 18, B from Horsfield S.n. DRAWN BY ROSEMARY WISE.

\section{Typifications}

Strobilanthes crispa (L.) Blume (1826: 798).

Ruellia crispa L. (Linnaeus 1753: 635). Type:

Unlocalised, presumably Java, Osbeck 116 (LINN-

HL804-11, lectotype designated here).

Sericocalyx crispus (L.) Bremek. (Bremekamp 1944: 163).
Although the lectotype has no original label, it was collected by Osbeck as indicated by Linnaeus (1753: 635). Osbeck is known to have visited Java and the collection number has been added as a result of studies by Hansen \& Fox Maule (1973). 
Strobilanthes crispa is apparently native in Java and Madura but has been cultivated elsewhere. Clarke (in sched.) identified the Osbeck collection as S. scabra but that species differs in the lanceolate scabrid (rather than ovate, pilose) bracts and is not known to occur outside cultivation in Indonesia.

Strobilanthes duclouxii Benoist (1922: 96). Type: China, Yunnan, Environs de Lan Ngui Tsi (?), 9 Aug. 1904, Pius Pi in Ducloux 2603 (lectotype P-00719313, selected here).

There are at least two isolectotypes at $\mathrm{P}$ and several specimens of the syntypes, all corresponding to the same species but the only one with Benoist's handwriting is the lectotype. It should be noted that not all specimens were distributed with the numbers cited by Benoist. We can only assume that numbers were changed at some stage during labelling or distribution.

Strobilanthes duclouxii is a synonym of $S$. extensa Nees.

Strobilanthes erecta C.B.Clarke (1907: 670). Type: Thailand, Chiangmai, Doi Chiang [Djieng] Dao, in grasiger Einsenkung, am Gipfel III, selten, $2160 \mathrm{~m}$, Hosseus 401a (holotype M-0168696, isotype fragment P-07193170).

Strobilanthes suborbicularis Imlay (1939: 118). Type:

Thailand, Chiangmai, Doi Lanka (Inthanon), Put 3302 (holotype $\mathrm{K}$, isotypes BK-257647, BM000906322, C-10005219).

Dossifluga suborbicularis (Imlay) Bremek. (Bremekamp 1944: 235).

Strobilanthes erecta is not represented in the Kew herbarium despite its description by Clarke (1907) and so was not taken up by Imlay (1939) who described the same species under the name $S$. suborbicularis. The holotype is in fact at Munich, where Hosseus' specimen is housed together with Clarke's manuscript description which was published by Hosseus some two years after Clarke's death in 2007.

Strobilanthes flava Kurz (1870: 78). Type: Based on Ruellia flava Roxb.

Ruellia flava Roxb. (Roxburgh 1832: 43), non R. flava Pers. (Persoon 1806). Type: Myanmar, Pegu, near Rangoon, F. Carey s.n. (no specimen preserved, lectotype Roxburgh image No. 2077 at K, epitype S. Kurz 2130 (K-000883167), both designated here). Hemigraphis flava (Kurz) C.B.Clarke (1884: 426).

Sericocalyx flava (Kurz) Bremek. (Bremekamp 1944: 163).
Strobilanthes phyllostachya var. dura C.B.Clarke (1884: 446). Type: Myanmar, (Rangoon), McClelland s.n. (lectotype K-000883003, designated here).

Sericocalyx durus (C.B.Clarke) Bremek. (Bremekamp 1944: 163).

The typification of Strobilanthes flava is somewhat complicated. It was originally described as Ruellia flava by Roxburgh, but no specimen was preserved so the only possible type is the Roxburgh painting at Kew. Ruellia flava Roxb. is illegitimate, being a later homonym of R. flava Pers. Strobilanthes flava was first cited with Ruellia flava Roxb. as basionym by Kurz (1870: 78) where he treated it erroneously as the correct name for Strobilanthes scabra Nees. Kurz later provided a full description of S. flava in the Forest Flora of British Burma (Kurz 1877: 243). The specimen designated above as epitype (Kurz 2130) is from the same area (Pegu Yoma) as the Carey collection but was collected and annotated by Kurz. It should serve to resolve any ambiguity in the interpretation of the Roxburgh plate.

Strobilanthes klossii (S.Moore) Y.F.Deng (2019: 204). Hemigraphis klossii S.Moore (1916: 133). Type: Indonesia, Western New Guinea, Utakwa R., Kloss s.n. (lectotype BM, designated by Moylan et al. (2002: 797), of which the portion at top of sheet, labelled Utakwa River to Mt. Carstensz, alt "Gauve" camp and in pencil above 'CC Oct Nov 12', second step designated here; isolectotype K000882762).

Unfortunately, when this was lectotypified by Moylan et al. (2002), it was not noted that there were three separate collections by Kloss mounted on the same sheet. In order to avoid ambiguity, a second step lectotypification is made above selecting the collection in the upper part of the sheet as the lectotype.

Strobilanthes sabiniana (Lindl.) Nees (1832: 86).

Ruellia sabiniana Wall. ex Lindl. (Lindley 1829: t. 1238). Type: a cultivated plant from Meghalaya, India, (Lectotype CGE ex Herb. Lindley, unlabelled portion annotated H.H.S (Herbarium Horticultural Society) on bottom right of sheet labelled Ruellia sabiniana Wallich, designated here).

The type is a plant cultivated in a hot house of the Horticultural Society of London (now the Royal Horticultural Society) grown from material obtained from the Calcutta Botanical Garden. The plant originated from near Pundua in the Khasi Hills of Meghalaya State, India, where it was probably collected by F. da Silva. 
Strobilanthes scabra Nees (1832: 84). Type: Bangladesh, Silhet, Wallich 2393a (K-001115843), lectotype, designated here.

There are four specimens in the Wallich collection in the Kew Herbarium associated with the name Strobilanthes scabra. Wallich 2377 ex Herb Wight, representing Nees' gamma variety, is $S$. heteromalla T.Anderson and is not further considered here. Nees' alpha variety is represented by Wallich 2393c (K-001115845) from Prome and is S. phyllostachya Kurz as recognised by Clarke's annotation. The remaining two specimens Wallich 2393a (K-001115843) and 2393b (K-001115844) are both from Sylhet and both represent the plant long recognised as S. scabra. Wallich 2393a is marginally the more complete specimen and is, therefore, selected as lectotype.

There are duplicates of Wallich 2393a in various herbaria including Edinburgh (E) and Nees' own herbarium at Graz (GZU). We have rejected the specimens at Graz for consideration as lectotype as Nees is known to have based his descriptions on Wallich's collections during his visit to London (De Candolle \& Radcliffe-Smith 1981), even though he rarely annotated them. Contrastingly, the specimens in Graz are annotated by Nees but probably at a date after 1840, as Strobilanthes is treated as masculine in these annotations whereas in the 1830 s he always treated the generic name as feminine, as did Blume, the original author (Wood 1994a).

There is an issue over the type location of Sylhet. This lies within the borders of Bangladesh. Most specimens of Strobilanthes labelled as from Sylhet originate from the Khasi Hills to the north, which lie within India. However, S. scabra is a plant of the Bengal plains so the type location probably lies within Bangladesh.

Strobilanthes secunda T.Anderson (1867: 480). Type: India, Assam, Simons 23 (lectotype K-001096878, designated here).

Ditrichospermum secundum (T.Anderson) Bremek. (Bremekamp 1944: 189).

Anderson cited five different collections as syntypes but only two of these at Kew bear his annotation, a Griffith collection and Simons 23, which he specifically cites as having seen at Kew. In view of this and the fact that the Griffith collection lacks an inflorescence, Simons 23 is designated as lectotype.

Strobilanthes thomsonii T.Anderson (1867: 478). Type: India, Sikkim, Ratong to Yoksum, $2500-5000 \mathrm{ft}$ [c. 750 - $1500 \mathrm{~m}$ ], 4 Oct. 1862, T. Anderson 1042 (lectotype BM-000906317, designated here).
Strobilanthes thomsonii var. serratifolia T.Anderson (1867: 478). Type: India, Sikkim, Kulhait \& Rumaum, T. Thomson s.n. and T. Anderson s.n. (syntypes, not found at $\mathrm{K}$, possibly present at CAL).

Anderson cited seven collections as syntypes of Stroboilanthes thomsonii and we have selected as lectotype the only specimen we have seen with Anderson's annotation.

Anderson drew attention to the variation in Strobilanthes thomsonii as did Clarke (1884: 467). Very robust forms, such as Wood 6824 (E, FHO) and 7496 (E, FHO), both from Bhutan, may correspond with Anderson's var. serratifolius. However, the inflorescence can be very variable, sometimes lax and formed of branched axillary racemes as in Wood 6824 but sometimes condensed, unbranched and \pm fasciculate as in Wood 7495 (E, FHO), also from Bhutan. The corolla of the last specimen is around $3 \mathrm{~cm}$ long whereas in Wood 5971 (E, FHO) from Bhutan the inflorescence is slender and the corolla a mere $2 \mathrm{~cm}$ long.

Although apparently common in Bhutan, Sikkim and neighbouring parts of Nepal and Darjeeling district, Strobilanthes thomsonii is rarely collected further east, but we have seen specimens from Arunachal Pradesh (Ludlow, Sherriff E Taylor 14202 [ BM]), the Tizu River in Nagaland (Bor 6798 [K] and Sirhoi in Manipur (Kingdon Ward 18204 [BM. NY]).

Strobilanthes yunnanensis Diels (1912: 164). Type: China, Yunnan, eastern flank of the Lichiang Range, G. Forrest 2361 (lectotype E-00047318, chosen here, isolectotypes BM-000810989, GH-00063067, K-000882826, P-00719465).

This specimen is chosen here as lectotype rather than the other cited specimen, Forrest (7)616, partly because it is the more ample specimen and partly because the number (7)616 was not cited correctly.

\section{Acknowledgements}

We would like to thank Elizabeth Moylan for the notes she left after completing her DPhil at Oxford. These have helped in the delimitation of Strobilanthes moylaniae, S. javanica and of the undescribed species from Sumba. Various people have helped in tracing records of the species discussed in this paper, particularly Ranee Prakesh (BM), Jan Wierina (L) and Denis Filer (OXF). We are also grateful to Rosemary Wise for preparing the drawings that accompany the text and to John Baker for help in preparing the plates. We are grateful for loans from various institutions, particularly $\mathrm{BM}, \mathrm{CANB}, \mathrm{K}$ and $\mathrm{L}$. 
Open Access This article is licensed under a Creative Commons Attribution 4.0 International License, which permits use, sharing, adaptation, distribution and reproduction in any medium or format, as long as you give appropriate credit to the original author(s) and the source, provide a link to the Creative Commons licence, and indicate if changes were made. The images or other third party material in this article are included in the article's Creative Commons licence, unless indicated otherwise in a credit line to the material. If material is not included in the article's Creative Commons licence and your intended use is not permitted by statutory regulation or exceeds the permitted use, you will need to obtain permission directly from the copyright holder. To view a copy of this licence, visit http://creativecommons.org/ licenses/by/4.0/.

\section{References}

Anderson, T. (1867). An Enumeration of the Indian species of Acanthaceae. J. Linn. Soc., Bot. 9: 425 526. https://www.biodiversitylibrary.org/item/ 8360\#page/431/mode/1up

Augustine, J. (2018). Strobilanthes in the Western Ghats, India. Malabar Natural History Society, Kozhikkode.

Bennett, J. R., Wood, J. R. I. \& Scotland, R. W. (2008). Uncorrelated variation in widespread species: species delimitation in Strobilanthes echinata Nees (Acanthaceae). Bot. J. Linn. Soc. 156: 131 - 141 .

Benoist, R. (1922). Descriptions d'espècies nouvelles du genre Strobilanthes (Acanthacées). Bull. Mus. Natl. Hist. Nat. 1922, 28: 94 - 99. https:// www.biodiversitylibrary.org/bibliography/5943\#/

Blume, C. L. (1825 - 26). Bijdragen tot de flora van Nederlandsch Indie. Lands Drukkerij, Batavia. https://doi.org/10.5962/bhl.title.395.

Boerlage, J. G. (1899). Acanthaceae. In: Handleiding tot de kennis der Flora van Nederlandsch Indï̈ 2: 605 - 664. Brill, Leiden. https://www.biodiversitylibrary.org/ bibliography/289\#/

Bremekamp, C. E. B. (1944). Materials for a monograph of the Strobilanthinae. Verh. Kon. Ned. Akad. Wetensch. Afd. Nat., Sect. 2, 41 (1): 1 - 305.

Candolle, R. de \& Radcliffe-Smith, A. (1981). Nathaniel Wallich, MD, PhD, FRS, FLS, FRGS, (1786 - 1854) and the Herbarium of the Honourable East India Company, and their relation to the de Candolles of Geneva and the Great Prodromus. Bot. J. Linn. Soc. 83 (4): 325 - 348. https://doi.org/ 10.1111/j.1095-8339.1981.tb00355.x.

Carine, M. A. \& Scotland, R. W. (1998). Pollen morphology of Strobilanthes (Blume (Acanthaceae) from southern India and Sri Lanka. Rev. Palaeobot. Palynol. 1003: 143 - 165.
\& __ (2002). Classification of Strobilanthinae (Acanthaceae); trying to classify the unclassifiable? Taxon 51: $259-279$.

Clarke, C. B. (1884). Acanthaceae. In: J. D. Hooker, Flora of British India 4: 387 - 558. L. Reeve \& Co, London. https://www.biodiversitylibrary.org/bibli ography/678\#

(1907). In: C. C. Hosseus, Die aus Siam bekannten Acanthaceen. Bot. Jahrb. Syst. 41: 62 73. https://www.biodiversitylibrary.org/item/703\#

(1908, dated 1907). Acanthaceae. In: G. King \& J. S. Gamble (eds), Materials for a Flora of the Malayan Peninsular. J. Asiat. Soc. Bengal, pt. 2, Nat. Hist. 74 (3): 628 - 728. https://www.biodiversity library.org/item/105377\#

Craib, W. G. (1913). Contributions to the Flora of Siam. Additamenta IV. Bull. Misc. Inform., Kew 1913: 199 - 204. https://www.biodiversitylibrary.org/bib liography/10719\#/

Deng, Y. F. (2019). Transfer of the Philippine species of Hemigraphis Nees to Strobilanthes Blume (Acanthaceae). Phytotaxa 404 (5): 203 - 208. https://doi.org/10.11646/phytotaxa.404.5.3

Diels, F. L. E. (1912). Plantae Chinenses Forrestianae - New and imperfectly known species. Notes Roy. Bot. Gard. Edinburgh 5 (25): 161 - 308. https:// www.biodiversitylibrary.org/bibliography/43948\#/

Hansen, C. \& Fox Maule, A. (1973). Pehr Osbeck's collections and Linnaeus Species Plantarum (1753). Bot. J. Linn. Soc. 67: 189 - 212.

Hu Chia-chi, Deng, Y. F., Wood, J. R. I. \& Daniel, T. F. (2011). Acanthaceae in Flora of China, Vol. 19: 369 477. Harvard University Press, Cambridge, Mass.

Imlay, J. B. (1939). Contributions to the Flora of Siam. Additamentum LI. New and Re-Named Siamese Acanthaceae. Bull. Misc. Inform., Kew 1939: 109 150. https://doi.org/10.2307/4111677

IUCN (2012). Guidelines for application of IUCN Red List Criteria at Regional and National Levels. International Union for the Conservation of Nature, Gland.

Kurz, S. (1870). On some new or imperfectly known Indian plants. J. Asiat. Soc. Bengal, Pt. 2, Nat. Hist. 39: 61 - 91. https://www.biodiversitylibrary.org/ bibliography/51678\#/

(1871). On some new or imperfectly known Indian plants. J. Asiat. Soc. Bengal, Pt. 2, Nat. Hist. 40: 45 - 78. https://www.biodiversitylibrary.org/ bibliography/51678\#/

(1877). Forest Flora of British Burma, Vol. 2. Government Printer, Calcutta.

Lindley, J. (1829). Ruellia sabiniana. Edwards's Bot. Reg. 15: t. 1238.

Linnaeus, C. (1753). Species Plantarum 2: 635. Laurentii Salvii, Holmiæ.

Moore, S. (1916). Acanthaceae. In: H. N. Ridley (ed.), Report on the Botany of the Wollaston Expedition to Dutch New Guinea 1912 - 13. Trans Linn. Soc. 
(London), Bot. 9: 132 - 136. https://www. biodiversitylibrary.org/item/13690

Moylan, E. C., Pennington, R. T. \& Scotland, R. W. (2002). Taxonomic Account of Hemigraphis Nees (Strobilanthinae-Acanthaceae) from the Philippines. Kew Bull. 57: 769 - 825.

, Bennett, J. R., Carine, M. A., Olmstead, R. G. \& Scotland, R. W. (2004). Phylogenetic Relationships among Strobilanthes s.l. (Acanthaceae): Evidence from ITSNRDNA, TRNL-F CPDNA, and Morphology. Amer. J. Bot. 91: $724-735$.

Nees Von Esenbeck, C. G. (1832). Acanthaceae Indiae Orientalis. In: N. Wallich, Plantae Asiaticae Rariores 3: 70 - 117. Treuttel, Würtz \& Ritter, London. https:// www.biodiversitylibrary.org/bibliography/468\#/

(1847). Acanthaceae. In: A. P. de Candolle (ed.), Prodromus systematis naturalis regni vegetabilis 11: 46 519. Masson, Paris. https://www.biodiversity library.org/bibliography/286\#/

Nurulaini, C. A. C., Noraini, T., Latiff, A., AmirulAiman, A. J. \& Noor-Syaheera, M. (2017). Pollen morphology of selected species of Ruellioideae (Acanthaceae) in Peninsular Malaysia. Malayan Nat. J. 69 (2): $39-51$.

Persoon, C. H. (1806). Synopsis Plantarum Vol. 2 (1). Apud J. G. Cottam, Tubingae.

Roxburgh, W. (1832). Flora Indica (ed. Carey), Vol. 3. Serampore. https://doi.org/10.5962/bhl.title.590

Schmutz, E. (1988). Periodical Flowering in Sericocalyx timorensis (Acanthaceae). Fl. Malesiana Bull. 10 (1): $19-20$

Steenis, C. G. Van (1942). Gregarious flowering of Strobilanthes (Acanthaceae) in Malaysia. Ann. Roy. Bot. Gard., Calcutta $150^{\text {th }}$ anniversary volume: $91-97$.
(1950). Flora Malesiana 1: Cyclopaedia of Collectors. Noordhoff-Kolff N.V Djakarta.

Terao, H. (1983). Taxonomic study of the genus Strobilanthes Blume Acanthaceae: generic delimitation and infrageneric classification. Ph.D dissertation, Kyoto, Japan.

Tripp, E. A., Daniel, T. F., Fatimah, S. \& McDade, L. A. (2013). Phylogenetic relationships within Ruellieae (Acanthaceae) and a revised classification. Int. J. Pl. Sci. 174: 97 - 137. https://doi.org/10.1086/668248

Wood, J. R. I. (1994a). Nees, Arnott \& some forgotten Acanthaceae types from Asia. Edinburgh J. Bot. 51: 103 115. https://doi.org/10.1017/S096042860000175X

(1994b). Notes relating to the Flora of Bhutan: XXIX. Acanthaceae, with special reference to Strobilanthes. Edinburgh J. Bot. 51: 175 - 273. https://doi.org/10.1017/S0960428600000871

(2014). Strobilanthes attenuata. Curtis's Bot. Mag. 31

(2): $154-167$.

Bennett, J. R. \& Scotland, R. W. (2003). Notes on Strobilanthes: the Sympagis group. Kew Bull. 58: 131 - 173. \& Scotland, R. W. (2009). New and little known species of Strobilanthes (Acanthaceae) from India and South East Asia. Kew Bull. 64: 3 - 47. https:// doi.org/10.1007/s12225-009-9098-2

Zollinger, H. \& Moritzi, A. (1845). Botanische reis van den Herr Zollinger. Natuur-en Geneesk. Arch. Ned.Indië 2: 548 - 587. https://www.biodiversity library.org/bibliography/14243\#/

\section{Publisher's Note}

Springer Nature remains neutral with regard to jurisdictional claims in published maps and institutional affiliations. 